definite structure in the human body. His last rival in this regard was the late C. B. Lockwood of St. Bartholomew's. Prof. Whitnall hails from Lancashire and he entered Owens College in 1894. Afterwards he was associated with St. 'Thomas's and for long with Oxford. In 1919, after war service with the 0xford Hussars, he went as professor of anatomy to McGill University, Montreal. There he remained until 1934, when he took the chair at Bristol, from which he is now retiring.

Dr. J. M. Yoffey has been appointed to succeed Prof. Whitnall in the chair of anatomy in the University of Bristol. Like his predecessor, Yoffey is a Manchester man, qualifying from the University of Manchester in 1926. Dr. Yoffey has had a brilliant career both as a student in Manchester and as a teacher at University College, Cardiff. More than this, he has had the great advantage of a Rockefeller Scholarship, which enabled him to carry on his researches in the United States in association with Prof. Drinker. As a research man Yoffey's name is permanently associated with the problems of lymphatics and lymphatic pathways. In this realm he has won wide recognition by reason of the thoroughness and the accuracy of his methods. When, in the post-War period, the Anatomical School of Bristol is reconstructed, we may look to see it as the centre of active investigation and research, and as the department to which many will go for inspiration and for knowledge of one of the most important subjects in which human anatomy impinges on clinical investigation.

\section{Marine Biological Association's Laboratory: Air Raid Damage}

DURING the recent air-raids on Plymouth, the Laboratory of the Marine Biological Association suffered severely. The buildings, though still standing, have sustained heavy damage. All windows except a few on the south side of the top floor of the main building have gone; ceilings are down, doors wrenched off, and much structural damage caused by blast. The director's house was completely burnt out. The Library, very fortunately, is intact except for the loss of windows and the skylight, and it has now been made waterproof. At the eastern end of the north building damage is most severe, but the greater part of the equipment and apparatus is intact. The Easter-class house will no doubt have to be rebuilt, but most of the roof remains. Other outbuildings, including the dogfish house, director's garage and stores, and the constant temperature rooms, have all sustained damage. The exact extent of the structural damage to the buildings cannot be determined without expert assistance, but it is hoped that the laboratories themselves can be restored. The tanks on the north side of the Aquarium burst and the supply pipes broke, but it is hoped that some part of the circulation may be restored before very long.

It will evidently be a long time before permanent repairs can be undertaken. Since materials for urgent work are extremely short, the cellotex sheeting on the first and second floors of the main laboratory is being taken down and used to replace windows. It is hoped to fit a small glass pane in each room, and if the cellotex is well painted, it is expected to remain weatherproof for a year or two. In a few weeks it may be possible to accommodate research workers who require only limited facilities, but this must depend largely upon the restoration of electricity and water supplies. There is no difficulty concerning general administration, as most documents have been salved. For the time being it will not be possible to supply orders for specimens, but it is hoped that in the course of a few weeks some of the normal facilities will be available.

\section{University of Glasgow: Air Raid Damage}

WhILE the University of Glasgow has as yet received no direct hit during recent air raids, all the windows of the main University buildings facing the park have been shattered. The Departments of Physiology, Public Health and Zoology have lost most of their windows, while many window frames and ceilings have been damaged. Some of the class rooms are temporarily unusable. Fortunately the damage to the contents of the buildings is quite negligible, and none of the personnel, staff or students, was injured although there were fire patrols in all the buildings. No other scientific institution in Glasgow appears to have been damaged.

\section{City Museum, Leeds: Air Raid Damage}

During recent air raids, the City Museum at Leeds suffered. The principal damage was done to the bird room and to the collections of medals and local tokens. Cases containing geological, archæological and zoological exhibits suffered from blast, but their contents are intact. Generally speaking, a large percentage of the disturbed material can be recovered. A collection of birds eggs survived a fall of 20 feet.

\section{Annals of the Botanic Gardens, Buitenzorg}

UNTIL recently the Annales du Jardin botanique de Buitenzorg were published at Leyden. As the European territory of the kingdom of the Netherlands is now occupied by the Germans, a new series under the title of Annals of the Botanic Gardens, Buitenzorg, has been started at Java. This periodical will cover the whole field of pure botany, including plant physiology, morphology, anatomy, cytology, ecology and microbiology. It will contain contributions by the regular staff and visitors of the scientific institutes of the Botanic Gardens, as well as from other sources. The editors mailing list is, however, not available in Java. As it is intended to continue exchange as usual, it is necessary to renew or confirm each exchange. The same holds for subscriptions to the new series. The price per volume is fixed at fl. 10. Therefore, subscribers and other persons interested in this periodical should communicate with the Director of the Botanic Gardens, Buitenzorg, Java. Dutch East Indies. 